\title{
ASSOCIATIONS OF HEALTHY BEHAVIOR AND ENVIRONMENT WITH ACUTE RESPIRATORY INFECTION IN JEPARA, CENTRAL JAVA
}

\author{
Saekhol Bakri, Aras Utami, Arwinda Nugraheni, Dodik Pramono, \\ Hari Peni Julianti, Dea Amarilisa Adespin
}

Department of Public Health, Faculty of Medicine, Universitas Diponegoro

\begin{abstract}
Background: According to earlier studies, except during the neonatal period, Acute Respiratory Infections (ARIs) are the most common causes of both illness and mortality in children under five, who average three to six episodes of ARIs annually regardless of where they live or what their economic situation is. This study aimed to determine the associations of healthy behavior and environment with acute respiratory infection in Jepara, Central Java.

Subjects and Method: A cross-sectional study was conducted in Mororejo village, Mororejo, Jepara, Central Java, from January to February 2018. A sample of 210 families were selected for this study. The dependent variable was ARIs. The independent variables were health behavior and environmental factors. The data were collected by questionnaire. Data on ARIs were taken from medical record. Crude (bivariate) analysis was carried out to show association with prevalence ratio (PR) used as a measure of association and chi square to show statistical significance.

Results: Incidence of ARIs was associated with smoking $(\mathrm{PR}=1.44 ; \mathrm{CI}=1.10$ to 1.88; $\mathrm{p}=0.014)$, poor ventilation $(\mathrm{PR}=1.78 ; \mathrm{CI}=1.12$ to $2.83 ; \mathrm{p}=0.015)$, and crowded dwelling $(\mathrm{PR}=3.61 ; \mathrm{CI}=1.37$ to $9.50 ; \mathrm{p}=0.009)$. The associations of ARIs with washing hand, garbage disposal, bin ownership, floor cleaning, room light, and poultry ownership, were statistically non-significant.

Conclusion: Incidence of ARI is associated with smoking, poor ventilation, and crowded dwelling.
\end{abstract}

Keywords: acute respiratory infections, health behavior, environment

\section{Correspondence:}

Aras Utami. Department of Public Health, Faculty of Medicine, Universitas Diponegoro, Semarang, Central Java. Email: aras.utami@gmail.com.

Mobile: 081225273747.

The 4th International Conference on Public Health Best Western Premier Hotel, Solo, Indonesia, August 29-30, 2018 | 173 https://doi.org/10.26911/theicph.2018.03.04 